\title{
Effects of Enterprise Risk Management (ERM) and Economic Issues on the Performance of Manufacturing Sector-SMEs in Malaysia - A Conceptual Framework
}

\author{
UmmuKhadijah Abdul Rauf, JuhainiJabar, NusaibahMansor
}

\begin{abstract}
This study aims to construct a conceptual framework that describes effect of Enterprise Risk Management (ERM) on the relationship among organizational performance and economic issues. The study intended to establish whether ERM adoption and economic issues influence the performance of Small and Medium Enterprises (SMEs) as focusing in manufacturing sector. However, as compared to large businesses, small businesses became one of the highest failure rates. ERM is a form of micro risk management and a full approach to identify risk in all purposeful areas. However, based on previous studies, the study to examine the practices in adopting ERM especially in SMEs and the performance of SMEs are still lacking. Hence, the area of this paper will be focus on SMEs manufacturing which are 380 registered SMEs that listed under SME Corp. Malaysia.
\end{abstract}

Keywords: Adoption, economic issues, enterprise risk management, institutional theory, Malaysia, performance, small

\section{INTRODUCTION}

The concept of business under SMEs is one of the providers in handling opportunity in term of employment opportunities and welfare promise. SME also has been promoted by governments and politicians in programs concept like an entrepreneurship development [12]. Thus, to increase performance in SMEs has more challenging in order to find the variables which may influencing the performance of SMEs not in the short term but for long term. If this happen SMEs can be one of the guidelines for developing countries in economic and one of the source developments in entrepreneurship, still to achieve this, the country need to make an effort in finding the most suitable tool for SMEs in handling the policies and regulations so SMEs will grow their business and expanding the business with more systematic [46]. In Malaysia, there are variety of SMEs industries and one of the GDP contributors in representing the total businesses in different sectors for the country. Thus, these industries played an important role for the country in term of economic development. Based on the previous contribution in SMEs, these industries became the most important to the economy for the country; the government took a step to support these industries in term of

Revised Manuscript Received on September 14, 2019.

UmmuKhadijah Abdul Rauf, Centre of Technopreneurship Development (CTeD), Faculty of Technology Management and Technopreneurship, UniversitiTeknikal Malaysia, Melaka, Malaysia.

JuhainiJabar, Centre of Technopreneurship Development (CTeD), Faculty of Technology Management and Technopreneurship, UniversitiTeknikal Malaysia, Melaka, Malaysia. (Email juhaini@utem.edu.my)

NusaibahMansor, Centre of Technopreneurship Development (CTeD), Faculty of Technology Management and Technopreneurship, UniversitiTeknikal Malaysia, Melaka, Malaysia. medium enterprises.

development for SMEs [37]. Thus, SMEs industries are one of the largest industries includes the different group of businesses such as trading, services, manufacturing and agriculture sectors. Hence, for many countries, the $90 \%$ total of business establishment came from SMEs. Furthermore, the Malaysian SMEs share 95\% of total establishments [42].

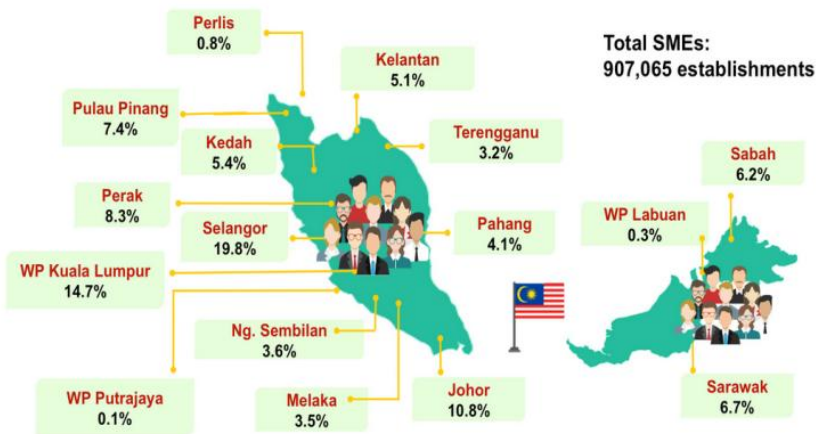

Fig. 1. Overview of SMEs in Malaysia by state [10]

For economy perspective in Malaysia, SMEs is recognized as the backbone of Malaysian economy [35] Previous researchers found there still lacking and limited in SMEs field in term of strategic planning for SMEs especially in Malaysia [18], [19], [39], [40]. The effects of crises on the SMEs are decreases in sales [51]. In 2016, the inflation at $2.0 \%$ to $3.0 \%$ as the price adjustments occurred in a few prices administered items [42]

For any country, a successful SME business environment directly translates to a successful economy [48]. Thus, SMEs growth its different following the countries. Malaysia has faced recession symptoms as decreasing in business development and the increases in unemployment rate which caused a huge problem for SMEs in Malaysia. Furthermore, Malaysian Government played their role in recognizing the importance of SMEs where they implemented the different policies, plans and organize programs to help SMEs in handling this type of problem [8]. However, SMEs has faced many problems due to not implementing ERM [3]. In addition, the study related to ERM implementation still lacking in Malaysian SMEs in the Manufacturing Sector. This leaves negative effects on the SMEs companies, and as a result, it is an essential element to take into account of economic issues in the determination of ERM adoption in Malaysian manufacturing SMEs.

SMEs manufacturing industries has been chosen as firm

Published By: 
for this study because SMEs industries played an important role in economic perspective and the main contributor of GDP for in many countries [36]. This study has been partially adopted the Fiedler contingency model by [13]. Previous studies stated the study on ERM adoption still lacking and limited specially in Small Medium Enterprise SMEs. Based on the previous studies this will be the gap need to be filled for this study. Thus, to fill the gap, this study aimed to study the ERM adoption and propose the ERM adoption for SME manufacturing in Malaysia. Furthermore, this study to propose a framework that will increase the level of the understanding ERM practices by investigating the relationship between risk factors and Malaysian SMEs manufacturing in adopting ERM as mediating variable. This paper will be focusing on the economic that extracted from Institutional Theory by [34], [35]. Based on this, the objectives of this paper are as follows:

1. To examine the effect of economic issues on SMEs manufacturing performance.

2. To examine the effect of economic issues on ERM effectiveness.

3. To examine the effect of ERM on SMEs manufacturing performance.

\section{LITERATURE REVIEW}

\section{A. Definition of ERM}

The definition of ERM is various according to the different interpretation but the accurate definition were developed by the Committee of Sponsoring Organizations of the Treadway Commission (COSO). COSO defined ERM as a process, affected by an entity's board of directors, management, and other personnel, applied in strategy setting and across the enterprise, designed to identify potential events that may affect the entity, and manage risk to be within its risk appetite, to provide reasonable assurance regarding the achievement of entity objectives [8].

The previous study stated that the implementation of ERM among companies will sustain the competitive advantages of firms as compared to the firms where managing and monitoring their risk itself without proper tools. ERM played an important role in helping the companies to strengthen the ability of the firm in planning their strategy in handling any risk [33]. Previous studies found that ERM implementation has improved performance of the firm [8], [25], [16], [20]. It is supported by previous studies stated the organizations have increased the level of awareness towards ERM benefits. [27]. Furthermore, many companies seek a positive approach which may help in reducing risk event in order to improve the opportunities in business [2].

\section{B. Economic and Firm Performance}

The discussion continues focusing on the relationship between economic issues and firm performance. SMEs represent for its economic growth and became one of the main contributors for all the enterprises in Kosovo which arise to 98 percent [4], [50]. SMEs industries focusing on two factors included developed and developing countries, thus these elements represent as the factor for economic growth for many countries [1], [23]. Furthermore, the factors influencing performance of the firm stated based on economic tradition context, in order to determine the factors of firm success; the external factors need to take into consideration as one of the important factors [30]. Previous researchers found the significant relationship between economic in manufacturing organization. For the researchers, it is very useful in providing strategy and as a foundation of theoretical perspective as to study on the relationship between market structure and performance of the firm [26], [50]. Hence, the critical issue is to fix tax issue in SMEs industries which caused critical in fixing business environment for SMEs industries [44]. Thus, when this occurred, SMEs industries had faced the interference in their market and caused inefficiency in economic context. At the same time, the allocation of resources for SMESs would be less efficient and turned to negative impact for these industries [15]. It is supported by previous studies found SMEs at the critical stages in economic development for many countries around the world. In addition, Malaysian economy is mainly based on SMEs [31].

$\mathrm{H} 1$ : There is a positive relationship between economic and performance of Malaysian manufacturing SMEs.

\section{Economic and ERM}

Furthermore, this study continues to discuss either there is a positive or negative relationship between economic factor and ERM. Another factor that has access in SMEs credit facilities is risk factor [10]. Thus, when the increases amount of debt happened in companies will result to default increase and there will be a result for cash flow limitations and at the same time the firm's interest payments may rely on external financing. When this happen, SMEs industries need to face the increases in financial risk. Moreover, SMEs can be said as one of the riskier enterprises based on previous studies and bring negative affect to the country especially for economic resources [12].

$\mathrm{H} 2$ : There is a mediating effect of implementation of ERM on economic issues and performance Malaysian manufacturing SMEs.

\section{ERM and Firm Performance}

The connection between ERM and firm performance remains to be discussed in this chapter. ERM is thought to be an efficient risk management method and is rapidly becoming the norm of best practice. In addition, previous studies have noted that organisations that have embraced a more integrated strategy, and as ERM, have encountered important company performance benefits in handling wideranging corporate hazards. Thus, in reality, academics and scientists generally agree that organisations using ERM will improve organisational efficiency [38]. SMEs have faced many problems due to not implementing ERM [2], [5], [6], [32]. Furthermore, SMEs lack of awareness in adopting the approach that can mitigate any potential risk from occur [23]. SMEs industries does not have any strategy to mitigate the risk from occur [45]. Thus, the improvement in 
implementing ERM which contributed to positive improvement in performance of organization. Findings of this research indicate that an improvement in the rate of ERM application in businesses contributed positively to the value of businesses [21], [48]. However, based on previous study found that firm's value comes from implementing ERM process [15]. This finding is supported with ERM positively and significantly influences the value of company [19]. Thus, there is a positive relationship between ERM practices and firm value [28].

H3: Perceived ERM has significant relationship with firm performance.

\section{PROPOSED FRAMEWORK\& RESULTS}

This study will continue to suggest theoretical framework. Recent studies have been used as a reference for risk management in the Malaysian manufacturing SMEs [3], [5], [6]. Businesses therefore need resources, procedures and structures that empower scheduled flexibility in order to attain and sustain success. Furthermore, Fred Fiedler's partly adopting and adapting in this study and using Fiedler's contingency model. This is linked to the practices of the ERM, the effectiveness of the ERM method and how it impacts the organisational result. The theoretical frameworks mentioned below guided this research. The theoretical framework for the research is shown in Fig. 2.

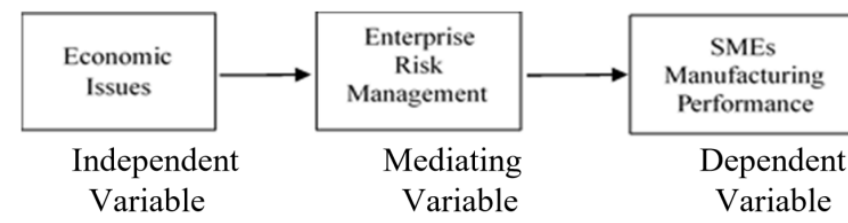

Fig. 2. Conceptual framework

\section{CONCLUSION}

The research indirect extends knowledge on the SME's readiness in adopting ERM and how it could benefit them. Such knowledge will be useful for the top management in being encouraged to become more proactive in promoting the ERM to increase the chances of success in business development, in order to improve productivity and increase competitiveness. The suggested framework that will explain the impact of ERM process as mediating variable in Malaysian manufacturing SMEs and the relationship between economic issues and organizational performance. Furthermore, this paper can be used as reference by future researchers when studying on the practices ERM. In addition, by reviewing the effectiveness of ERM in this paper, researchers might find the economic issues which frequently occurred in Malaysian SMEs manufacturing which could lead to the positive achievements of ERM adoption This is to make a development to offer the best strategies and driving the healthy practices forERM development in Malaysian companies and relationship with economic issues will disclose the different type of challenges and risks, frequently occurred in Malaysian manufacturing SMEs companies.

\section{ACKNOWLEDGMENT}

The authors would like to thank UniversitiTeknikal Malaysia Melaka (UTeM) for the Research University Grand Scheme (FRGS/1/2017/SS03/FPTT-CTED/F00348) that had supported this research.

\section{REFERENCES}

1. J. Miccolis and S. Shah, "Risk value insights: Creating value through enterprise risk management-A practical approach for the insurance industry," Tillinghast-Towers Perrin Monograph, 2001.

2. A Roslan and H. M. Dahan, "Internal audit and organizational performance: A conceptual framework," International Journal of Commerce, Business and Management, 2(4), 2013, pp. 212-215.

3. A. B Sim, "Turnaround for small businesses-A synthesis of determinants for action research, with reference to Malaysia," Malaysian Management Review, 26(3),1991, pp. $15-22$

4. A. K. Char, M. R. B. Yasoa, Z. Hassan, and M. Z Muhammad, "Small and medium enterprises (SMEs) competing in the global business environment: A case of Malaysia," International Business Research, 3(1), 2010, pp. 66-75.

5. A. Ndope, Strategic risk factors influencing sme growth: A case study of markmann and company limited. Master thesis, Nairobi: United States International University Africa, 2016.

6. A. P Liebenberg and D. W. Sommer, "Effects of corporate diversification: Evidence from the propertyliability insurance industry," Journal of Risk and Insurance, 75, 2008, pp. 893-919.

7. A. P. Liebenberg and R. E. Hoyt, "The determinants of enterprise risk management: Evidence from the appointment of chief risk officers," Risk Management and Insurance Review, 6(1), 2003, pp. 37-52.

8. A. Radam, M. L. Abu, and A. M. Abdullah, "Technical efficiency of small and medium enterprise in Malaysia: A stochastic frontier production model," International Journal of Economics and Management, 2(2), 2008, pp. 395-408.

9. B. G. Peters, Institutional Theory in Political Science: The New Institutionalism. Cheltenham: Edward Elgar Publishing, 2019.

10. B. Ramdani, P. Kawalek, and O. Lorenzo, "Predicting SMEs' adoption of enterprise systems," Journal of Enterprise Information Management, 22(1/2), 2009, pp. $10-24$.

11. C. Correia, D. Flynn, E. Uliana, and M. Wormald, Financial Management. Cape Town: Juta Legal and Academic Publishers, 2017.

12. C. Verbano and K. Venturini, "Managing risks in SMEs: A literature review and research agenda," Journal of Technology Management and Innovation, 8(3), 2013, pp. 186-197.

13. C. W. Hin, K. A., Kadir, \& A. M. Bohari, "The strategic planning of SMEs in Malaysia: Types of strategies in the aftermath of economic downturn," Asian Journal of Business and Management Sciences, 2(8), 2013, pp. 5159.

14. Committee of Sponsoring Organizations of the Treadway Commission (COSO), Enterprise risk managementintegrated framework: Executive summary and framework. New York: American Institute of Certified Public Accountants, 2004 
15. D. A. Razak, M. A. Abdullahand, and A. Ersoy, "Small medium enterprises (SMEs) in Turkey and Malaysia: A comparative discussion on issues and challenges," 15th Kuala Lumpur International Business Economics and Law Conference, 2018, pp. 1-12.

16. D. B. Audretsch, The Entrepreneurial Society. England: Oxford University Press, 2007.

17. D. North, Institutions, Institutional Change, and Economic Performance. New York: Cambridge University Press, 1990.

18. Department of Statistics Malaysia (DOSM), Economic cencus: Profile of small and medium enterprises. Putrajaya: DOSM, 2016.

19. E. S. N. Nermeen, "Risk Management in the light of travel agencies activity in Egypt," Journal of Faculty of Tourism and Hotels, Fayoum University, 10(2/2), 2014, pp. 408-426.

20. F. W. Lai, N. A. Azizan, and M. F. A Samad, "A strategic framework for value enhancing enterprise risk management," Journal of Global Business and Economics, 2(1), 2011, 23-47.

21. F. E. Fiedler, "A contingency model of leadership effectiveness," Advanced Experimental Social Psychology, 1, 1964, pp. 149-190.

22. I. N. Yalman, F. Demirkoparan, and O. Aras, "Financial crisis impact on SMEs and SMEs strategies during economic crises: A case of Sivas province," Sivas, Turkey. [Online]. Available: http://www.opf.slu.cz/kfi/icfb/proc2011/pdf/67_Yalman. pdf.

23. J. Freedman and C. Crawford. "Small business taxation," Dimensions of Tax Design: The Mirrlees Review, S. Adam, S. Bond, R. Chote, P. Johnson and G. Myles, Eds England: Oxford University Press, 2010, pp. 1028-1099.

24. J. McMillan and C. Woodruff, "The central role of entrepreneurs in transition economies," Journal of Economic Perspectives, 16(3), 2002, pp. 153-170.

25. J. Mirrlees, S. Adam, T. Besley, R. Blundell, S. Bond, R. Chote, M. Gammie, P. Johnson, G. Myles, and J. Poterba, Dimensions of Tax Design: The Mirrlees Review. England: Oxford University Press, 2010. Management (ERM) practices among Malaysian SMEs: The three steps process to identify adopters and nonadopters of ERM for SMEs," International Journal of Academic Research in Business and Social Sciences, 8(11), 2018, pp. 1232-1245.

27. K. A. Aziz and A. S. Yazid, "Enterprise Risk Management (ERM) practices among SMEs in Malaysia: A conceptual framework," International Conference on Empowering Islamic Civilization in the 21st Century, 2014, pp. 296-300.

28. L. A. Gordon, M. P. Loeb, and C. Y. Tseng, "Enterprise risk management and firm performance: A contingency perspective," Journal of Accounting and Public Policy,

29. M. K. Hashim, "Business strategy and performance in Malaysian SMEs: A recent survey," Malaysian Management Review, 35(2), 2000, pp. 1-10.

30. M. Turpin, Risk management in Europe: An investigation of medium sized enterprises. New York: McLennan Company (PTY) Ltd., 2002.

31. N. Waweru and E. Kisaka, "The effect of enterprise risk management implementation on the value of companies listed on the Nairobi stock exchange," Journal of Applied Finance and Banking, 3(3), 2013, pp. 81- 105.

32. O. O. Fatoki and A. V. A. Smit, "Constraints to credit access by new SMEs in South Africa: A supply-side analysis," African Journal of Business Management, 5(4), 2014, pp. 1413-1425
26. K. A. Aziz, M. Mahmod, and A. Yazid, "Enterprise Risk 28(4), 2009, pp. 301-327.

33. R. E. Hoyt and A. P Liebenberg. (2006). The value of enterprise risk management: Evidence from the U.S insurance. [Online]. Available: https://www.soa.org/globalassets/assets/files/resources/es says-monographs/2008-erm-symposium/mono-2008-mas08-1-hoyt.pdf.

34. R. E. Hoyt and A. P. Liebenberg, "The value of enterprise risk management," Journal of Risk and Insurance, 78(4), 2011, pp. 795-822.

35. R. E. Hoyt and A. P. Liebenberg, "The value of enterprise risk management," Journal of Risk and Insurance, 78(4), 2011, pp. 795-822.

36. R. E. White and R. C. Hammermesh, "Towards a model of business unit performance: An integrative approach," Academy of Management Review, 6(2), 1981, pp. 213 223.

37. R. Stern and J. Loeprick. (2007). Small business taxation Is this the key to formalization? Evidence from Africa and possible solutions. [Online]. Available: http://businessenvironment.org/dyn/be/docs/159/Coolidg e_Executive\%20Summary\%20English.pdf.

38. R. T. Lenz, "Determinants of organizational performance: An interdisciplinary review," Strategic Management Journal, 2(2), 1981, pp. 131-154

39. S. Duguh, "Entrepreneurship and small business: Strategic approach to alleviating poverty and corruption in Nigeria," GSTF Business Review, 3(1), 2013, pp. 57 66.

40. S. Gates, J. L. Nicolas, and P. L. Walker, "Enterprise risk management: A process for enhanced management and improved performance," Management Accounting Quarterly, 13(3), 2012, pp. 28-38.

41. S. Johnson, D. Kaufmann, and A. Shleifer, "The unofficial economy in transition," Brookings Papers on Economic Activity, 2, 1997, pp. 159-239.

42. H. Hashim, SME development framework: The Malaysian case. [Online]. Available: https://icsmee.org/wpcontent/uploads/2016/01/CairoSMEConferenceJan2015S ession3DatoHafsahMalaysi.pdf.

43. SME Corp Malaysia. Home. [Online]. Available: http://www.smecorp.gov.my/index.php/en/.

44. T. A. Ping and R. Muthuveloo, "The impact of enterprise risk management on firm performance: Evidence from Malaysia," Asian Social Science, 11(22), 2015, pp. 149159.

45. T. Janney and G. Dess, "The concept for entrepreneurs considered new challenges to the conventional wisdom," Journal of Business Venturing, 21(3), 2006, pp. 385-400.

46. United Nation. (2014). Entrepreneurship for development. [Online]. Available: http://unctad.org/meetings/en/SessionalDocuments/a69d3 20 en.pdf.

47. W. B. Nocco and M. R. Stulz, "Enterprise risk management: Theory and practice," Journal of Applied Corporate Finance, 18(4), 2006, pp. 8-20.

48. W. J. K. Muhammad and K. Muhammad, "An Overview of small and medium enterprises in malaysia and pakistan: Past, present and future scenario', Business and Management Horizons, 2(2), 2014, pp. 38-49.

49. W. Johnston, M. Leach, and A. Liu, "Theory testing using case studies in business-to-business research," Industrial Marketing Management, 28(3), 1999, pp. 201233.

50. World Bank, A better investment climate for everyone: World Development Report 2005. New York: The World 
Bank and Oxford University Press, 2005.

51. Z. Acs and D. Audretsch, Innovation and Small Firms. Cambridge: MIT Press, 1990.

\section{AUTHORS PROFILE}

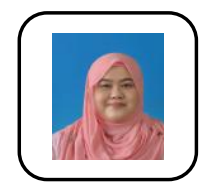

UmmuKhadijahbinti Abdul Raufis currently a Ph.D. student at UniversitiTeknikal Malaysia Melaka (UTeM), Faculty of Technology Management and Technopreneurship. She holds a Master in Business Administration (MBA) majoring in Technological and Technopreneurship from Technical University of Malaysia Malacca (UTeM). Her areas of research interest include the nature of Enterprise Risk Management on Small Medium Enterprises (SMEs) and the impact of this tool and the development of strategic risk management.

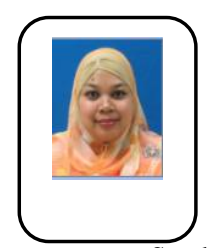

JuhainibintiJabaris an Associate Professor of Technology Management at Centre of Technopreneurship Development (CTeD), Faculty of Technology Management and Technopreneurship, at Technical University of Malaysia Malacca (UTeM). She holds a PhD in Business and Management, University of South Australia. She teaches strategic technology alliances, technology adoption, entrepreneurship development, research and methodology and business management. Currently, she is the Dean of Technology Management and Technopreneurship at the Technical University of Malaysia Malacca (UTeM). Her main research interests are Technovation, technopreneurship and performance of small business.

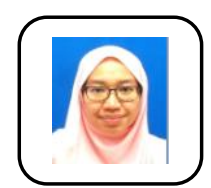

NusaibahMansoris a postgraduate lecturer at Centre of Technopreneurship Development (CTeD), Faculty of Technology Management and Technopreneurship, at Technical University of Malaysia Malacca (UTeM), where she teaches risk management and technology management. She holds a $\mathrm{PhD}$ in Business Administration at Aichi Institute of Technology, Japan. Currently, she is the Coordinator (Postgraduate) of Technology Management and Technopreneurship at the Technical University of Malaysia Malacca (UTeM). Her main research interests are in Management (Technology) \& Risk Management entrepreneurship and performance of higher education. 